\title{
Impact of Mineral Formation on Restoration of the Soil Structure in Nakhchivan AR and Geographical Spreading Legitimacy
}

\author{
Raez H. Aliyev \\ Institute of Soil Science and a Agrochemistry of ANAS. Az 1073. Baku.str. M.Rahim.5
}

Received: 30-11-2019; Revised: 21-12-2019; Accepted: 25-01-2020

\begin{abstract}
The silt fractions have a great impact in soil structural formation. If the soil-forming rocks do not disturb, crush, and weather, the soil-forming processes on them occur weakly, the organic substances cause the formation of the loamy stratums without completely turning. This mostly influences the initial soil-forming layers. The reproduction minerals in these soils cause initial minerals majority by occurring weakly. If these processes occur quickly, then they cause a gradual increase of the reproduction minerals and reduction of the initial minerals. The heights of the zones where the geographical spreading of such stratums is situated depend on levels.
\end{abstract}

Key words: Caolinite, chlorite, illite (hydroslude), mineral, montmorillonite, rock, structure

\section{INTRODUCTION}

The soddy-meadow, mountain alluvial gray and soddy mountain meadow soils which exposed to anthropogenic impacts are strongly unlike one another for their formation characters. A section of such soils (164) was applied in the Araz coast plain part, Sadarak plain part (section 1), and soddy mountain meadow (section 18). ${ }^{[1-5]}$

The section of the soddy-meadow soils (section 164) was applied in the zones near the Araz River. The soils formed here are considered to be consisted of the deposits which are brought by the Araz River. The soil-forming processes in here are very complex, possess the same structure on the genetic stratums. Sometimes, these stratums are quickly washed out by forming very weakly. The forming structures cover surface of the mean and little stones, deposits. These layers which are not performed by the river waters for a long time can form weak combinations of the organic substances. ${ }^{[6-10]}$

\section{Address for correspondence:}

Raez H. Aliyev

E-mail: volqa_5@mail.ru
These stratums can be turned into freckled-gravelly, sandy ones. Sometimes, a thickness of these soils became 3-5 and $25-50 \mathrm{~cm}$.

Mean inclined Sandarac plain soils (section 1) were brought by the Araz River, and afterward, the Jahannamdarasi River covers their surface. Chapan and Garasu are river deposits, they form mountain alluvial gray and bright gray-brown (chestnut) soils by influencing on soil structural restoration.

The soddy mountain meadow soils have weak metamorphosis genetic layers (section 18) by involving some high zones.

If the Araz coastal lowland is situated at $600 \mathrm{~m}$ above sea level, the soddy mountain meadow soils form high parts of Nakhchivan by occupying the heights till 850-100 $\mathrm{m}$ for the relief characters.

\section{Discussion and analysis of the work}

The soddy-meadow soils (section 164) were applied at $50 \mathrm{~m}$ of the north in the Diadin village of the Sharur plain, Tumasli zone from descending inclined lowland of the Araz coast. ${ }^{[11-15]}$

The soil stratums are the same for the morphogenetic structure and the blackish colors are found at 
the depth $(35-40 \mathrm{~cm})$. Only the upper layers are considered cultural-toamy stratums [Table 1].

The soddy-meadow soils possess a weak humid capacity according to the field humid capacity. More moisture is on upper and low layers - A 0-21 $\mathrm{cm}$ and C 101-120 cm, 22.41-23.99\% - a quantity of moisture decreases on the rest stratums.

Majority of the hydromorth state in these soils influences on the development of the soddy-meadow soils.

The soddy-meadow soils are considered alkaline soils for $\mathrm{pH}$ composition, the most number is on the stratums near subsoil and maternal rocks A/B 21-50, B 2 72-101, and C 101-120 cm - 8.3.

The soils have mean hygroscopic moisture and change by A 0-21 and A/B 21-50 cm, 4.08-5.63\%. The soddy-meadow soils have a weak bulky weight from a bulky weight point of view. The most quantity reaches $1.31 \mathrm{~g} / \mathrm{cm}^{3}$ (illuvial $\mathrm{B}_{2} 72-101 \mathrm{~cm}$ ).

For $\mathrm{CaCo}_{3}$ quantity, the soddy-meadow soils are weak calcareous, their most number is on the illuvial $\mathrm{B}_{2}$ and $\mathrm{C}$ layer, but changes by 12.68 $14.93 \%$ at $72-101$ and $101-120 \mathrm{~cm}$. Evidently, this is connected with the calcareous, gypsy rocks, and washing regime.

The mean inclined plain zonal mountain alluvial gray soils (section 1) are created in the zone of Sadarak plain.

These formed inclined plain zone mountain alluvial gray soils are brought since ancient times, the Araz deposits are related to the Jahannamdarasi, Chapan, and Garasu Rivers.

The field humid capacity mountain alluvial gray soils possess a weak moisture capacity. The most quantity is on $\mathrm{B}_{1}$ layer and forms $20.67 \%$.

Hygroscopic humidity in these soils is weak, reaches $2.61-4.95 \%$. The most reduction is on the maternal rock, C 126-160 cm, 2.62\%.

Some majority of the hydromorph structure shows itself in the whole soil profile.
From a bulky weight point of view, the mountain alluvial gray soils are considered non-hardened soils - 1.07-1.27 g/ $\mathrm{cm}^{3}$.

Change of the bulky weight in the mountain alluvial gray soils in such composition depends on the structure of the alluvial original rocks and distribution legitimacy.

These soils are considered weak alkaline soils for $\mathrm{pH}$ content, change by 7.9-8.1.

Humus substance is little in these soils - 0.30$1.33 \%$. The most number is on the upper alluvial stratums - A $0-20 \mathrm{~cm}-1.33 \%$.

More aridity of the climate and falling atmospheric precipitations causes quickly mineralization of the organic substance, sometimes its formation.

The mountain alluvial gray soils are weak for $\mathrm{CO}_{2}$ changes by $8.41-8.58 \%$ only on the upper layers.

$\mathrm{CaCO}_{3}$ number is more only on the upper stratums and changes by $19.1-19.5 \%$ in A0-20 and A/B 20$38 \mathrm{~cm}$ and diminishes on the low layers.

The soddy mountain meadow soils spread in the high zones of Nakhchivan AR and possess weak metamorphosed stratums.

Possessing mean humid capacity, the soddy mountain meadow soils are mostly on the illuvial stratums and change by $24.08-24.95 \%$ in $\mathrm{A} / \mathrm{B}$ and $\mathrm{B}_{1} 10-26$ and $26.48 \mathrm{~cm}$. Their number reaches $17.00 \%$ only on the maternal rocks.

Somewhat reduction of the field moisture supply on the maternal rock depends on a character of the rocks which form soddy mountain meadow soils. Increase of the field humid capacity on the illuvial layers depends on gradually washing out of silt fractions from upper layers and otherwise climatic factors.

Majority of hygroscopic moisture under hydromorph condition and mainly spreading on the illuvial stratums is connected with the somewhat majority of the atmospheric precipitations and gradual spreading of the silt particles, $\mathrm{A} / \mathrm{B}, \mathrm{B}_{1}$, and $\mathrm{B}_{2} 10$ $26,26-48$, and $48-65 \mathrm{~cm}$ changes by $8.42-8.66 \%$.

Table 1: Definition of some physical-chemical characters of the soddy-meadow soils in the low inclined descending plain zone

\begin{tabular}{|c|c|c|c|c|c|c|c|c|}
\hline Line No. & Name of the section & Depth cm & $\begin{array}{c}\text { Field humid } \\
\text { capacity } \%\end{array}$ & $\begin{array}{l}\text { Hygroscopic } \\
\text { humidity \% }\end{array}$ & pH & Bulky weight $\mathrm{g} / \mathrm{cm}^{3}$ & $\mathrm{CO}_{2} \%$ & $\begin{array}{c}\mathrm{CaCO}_{3} \text { according } \\
\text { to } \mathrm{CO}_{2}-\%\end{array}$ \\
\hline \multirow[t]{5}{*}{1} & \multirow{5}{*}{$\begin{array}{l}164 \\
\text { Sharur plain Tumasli } \\
\text { zone Diadin village } \\
\text { soddy-meadow soils }\end{array}$} & A $0-21$ & 22.46 & 5.63 & 8.0 & 0.91 & 1.48 & 3.36 \\
\hline & & $\mathrm{A} / \mathrm{B} 21-50$ & 15.60 & 4.08 & 8.3 & 1.25 & 4.73 & 10.73 \\
\hline & & $\mathrm{B}_{1} 50-72$ & 19.32 & 3.53 & 8.1 & 1.15 & 4.36 & 9.89 \\
\hline & & $\mathrm{B}_{2} 72-101$ & 16.61 & 2.91 & 8.3 & 1.31 & 5.56 & 12.68 \\
\hline & & C $101-120$ & 23.99 & 4.00 & 8.3 & t.e & 6.58 & 14.93 \\
\hline
\end{tabular}


Humus in these soils is somewhat more, A $0-10$ and $\mathrm{A} / \mathrm{B} 10-26 \mathrm{~cm}$ change by $3.07-3.31 \%$ on the alluvial upper layer and its quantity reaches $\mathrm{C} 78$ $105 \mathrm{~cm}-1.02 \%$ on the maternal rocks.

For a quantity of $\mathrm{CO}_{2}$ and $\mathrm{CaCO}_{3}$, the soddy mountain meadow soils are somewhat weakly provided calcareous soils.
This is a character peculiar to the soddy mountain meadow soils, depends on atmospheric precipitations and rocks. The physical-chemical features occurring in soils show their impact in mineral formation. The modern mineralogical compositions of the soddy meadow soils strongly differ from other soils [Figure 1-3].

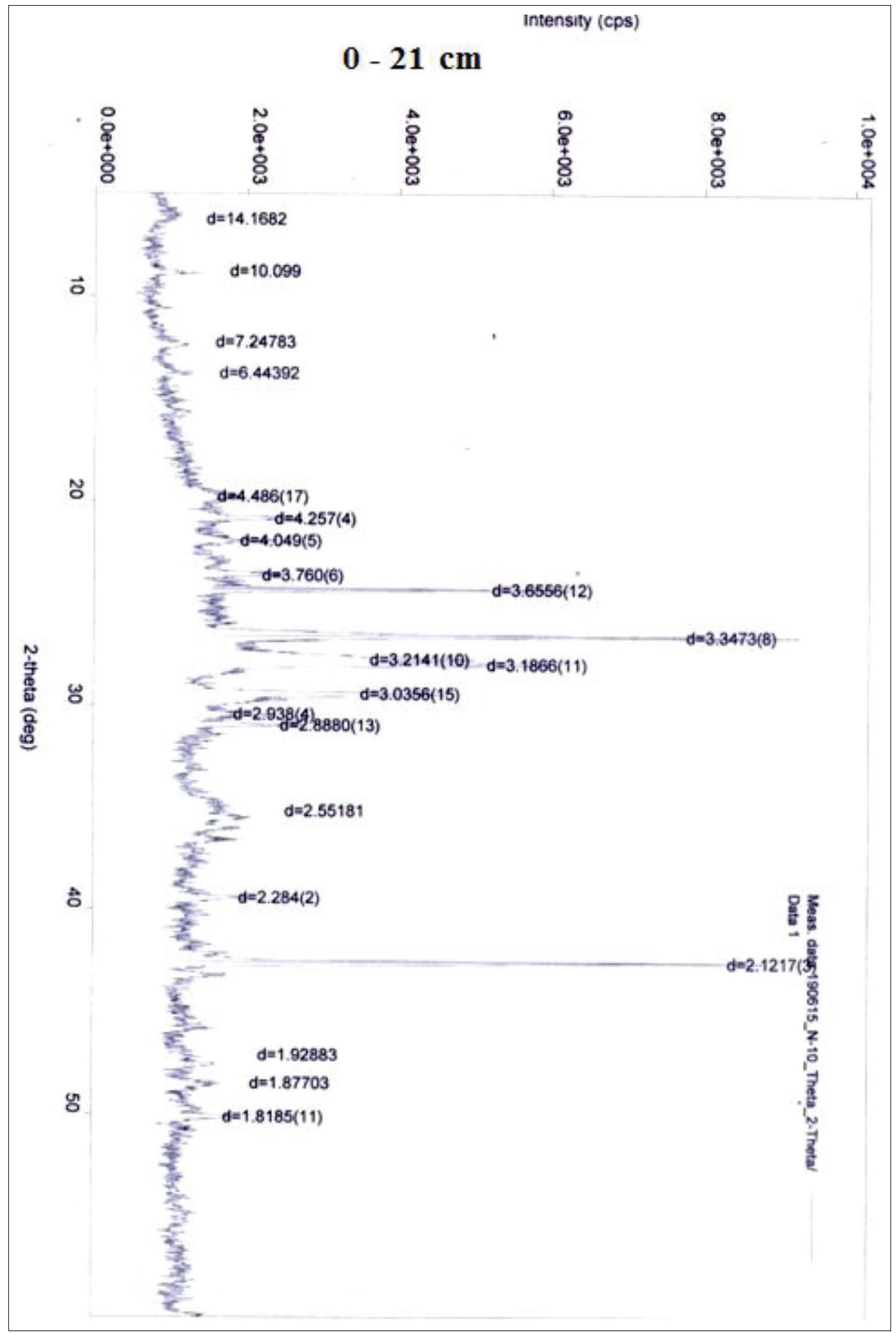

Figure 1: Modern mineralogical content of soddy-meadow soils in the Tumasli zone of the Sharur region, Nakhchivan AR 


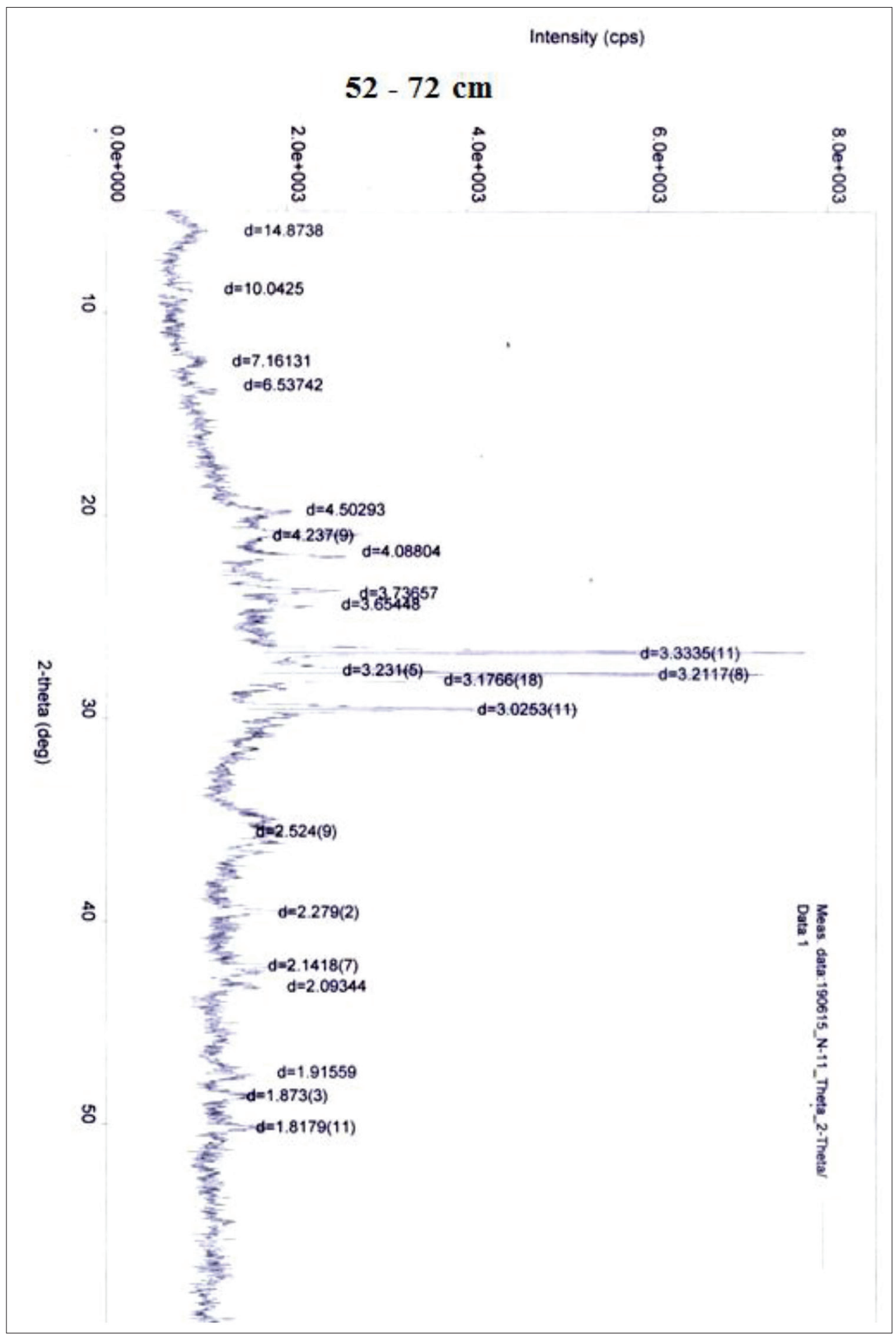

Figure 2: Modern mineralogical composition of the soddy-meadow soils in the Diadin village of Tumasli in the Sharur district, Nakhchivan AR

The consequences from an apparatus "Mini Flex600" show that montmorillonite, illite (hydroslude), and caolinite from high dispersion minerals are mostly spread [Tables 2 and 3].

The other high dispersion minerals are not reflected in these soils.
The mostly exceeding minerals are initial minerals. Montmorillonite mineral changes by $11.3-16.0 \%$ in soddy-meadow soils, they are mostly on the upper layers.

Illite (hydroslude) mineral changes by $4.2-7.3 \%$ in the soddy-meadow soils. 


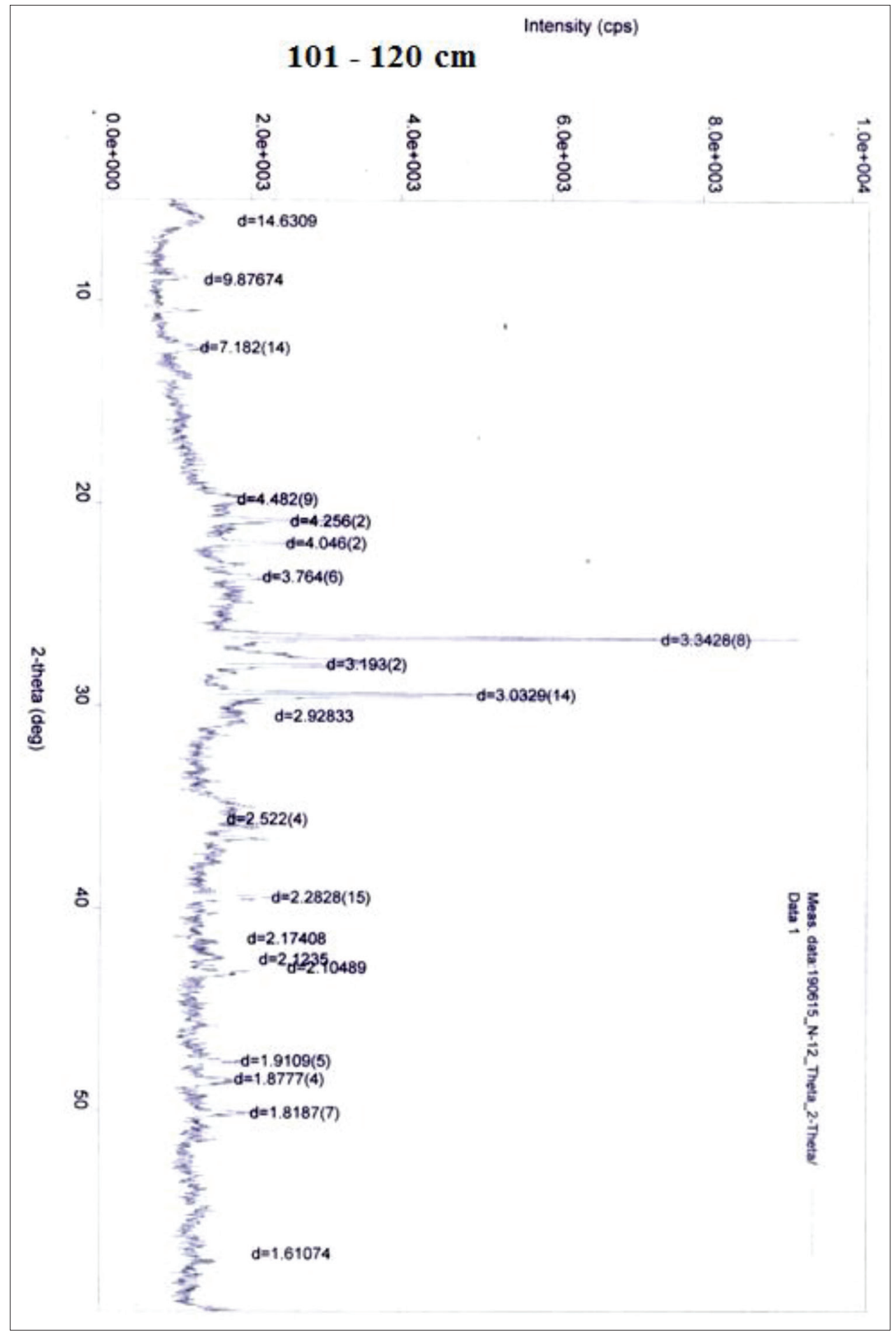

Figure 3: Modern mineralogical structure of the soddy-meadow soils in the Diadin village of Tumasli from the Sharur region, Nakhchivan AR

Majority of high dispersion minerals on the upper layers is connected with the content of the debris and precipitated silt fractions.

This depends on conditions mostly possessing an arid climate, Caolinite mineral in these soils changes by $9.2-11.3 \%$.
Their most quantity is on the maternal rocks, where the weathering-soil-forming processes quickly occur, they show their influence on formation of illite (hydroslude) and montmorillonite combinations.

From the initial minerals - d-kvarts $\left(\mathrm{SiO}_{2}\right)$ changes by $19.3-20.5$, field shpat $-9.6-16.1 \%$, calcite 
$\left(\mathrm{CaCO}_{3}\right)-9.8-17.8 \%$, hematite $\left(\mathrm{Fe}_{2} \mathrm{O}_{3}\right)-3.4-6.7 \%$, $\mathrm{NaCl}-1.4-6.4 \%$, and volcano ash $-10.2-15.2 \%$.

The high dispersion minerals decrease, the initial minerals increase.

From illite (in hydroslude), chlorite, weak caolinite, and mixed-stratified combinations are illite (in hydroslude) combination.

Illite combinations (in hydroslude) are from illite (in hydroslude), chlorite, weak caolinite, and mixedstratified combinations in the silt fractions mostly spread in the mountain alluvial gray soils of the Sadarak plain inclination [Figures 4 and 5].

From the mostly spread initial minerals are d-kvartz, field shpat, and zeolite.

The illite (hydroslude) mineral in the mountain alluvial gray soils widely spread over the whole profiles and shows itself on the following peaks $(1.00 \mathrm{~nm}, 0.500 \mathrm{~nm}$, and $0.334 \mathrm{~nm})$.

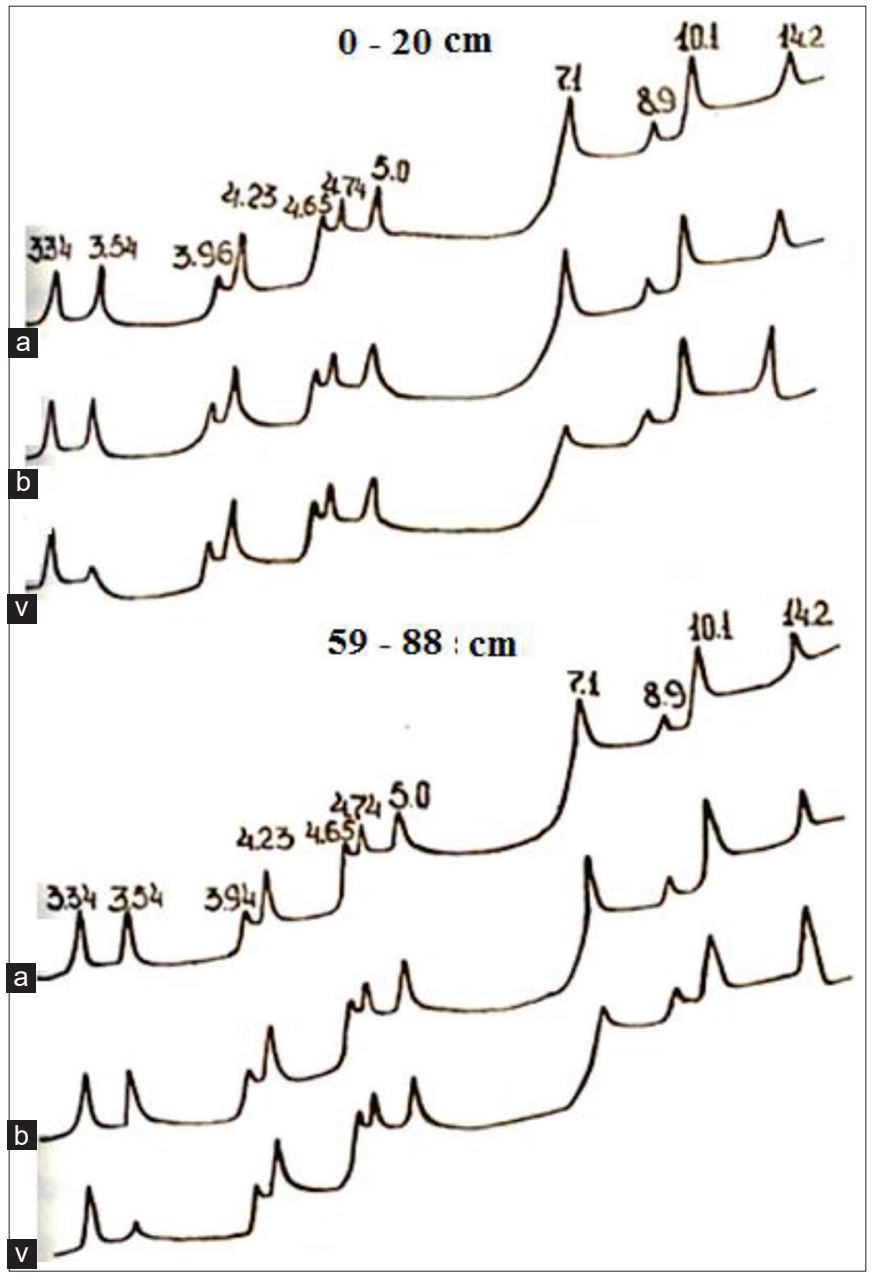

Figure 4: Definition of Roentgen diffractograms in silt fractions from mountain alluvial gray soils in the Sadarak plain, Nakhchivan AR $<0.001 \mathrm{~mm}$ (section 1). (a) In totally arid state; (b) while being saturated with glycerin; (v) while heating $550^{\circ} \mathrm{C}$
Chlorite mineral is in these soils, mostly on upper and middle stratums, it reaches $1.400 \mathrm{~nm}, 0.710 \mathrm{~nm}$, and $0.354 \mathrm{~nm}$ on the peaks. It weakens and shows its indications on the peaks, reaches $1.560 \mathrm{~nm}$ while being saturated with glycerin.

Caolinite mineral changes its peaks in silt fractions $-0.710 \mathrm{~nm}$ and $0.358 \mathrm{~nm}$.

Illite (in hydroslude), caolinite, and weak montmorillonite are found in silt fractions of the soddy mountain meadow soils [Figures 6 and 7].

Majority of illite on upper, middle, and low stratums does not change its peaks while being saturated with glycerin and heated till $550^{\circ} \mathrm{C}$.

Caolinite mineral loses its initial peaks and sometimes shortens while heating $550^{\circ} \mathrm{C}$. The peaks of caolinite mineral reach $0.700 \mathrm{~nm}$ and $0.358 \mathrm{~nm}$ by showing itself in silt fractions.

Minority of montmorillonite mineral and increase on low layers causes the formation of the montmorillonite-illite (hydroslude) combinations on mixed-stratified combinations.

Initial minerals are much in these soils and mainly consist of andesite, basalt, field shpat, kvartz, and serpentinite.

For the geographical spreading legitimacy, the soddy mountain meadow and soddy-meadow soils are somewhat initial soils from location features standpoint, they cause somewhat decrease of the

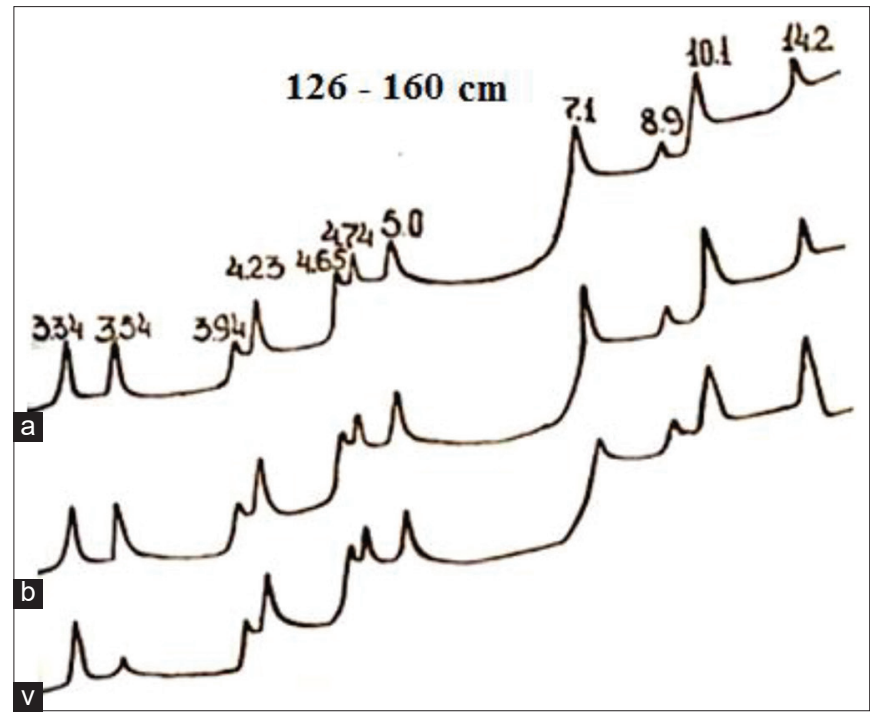

Figure 5: Definition of Roentgen diffractograms in silt fractions from mountain alluvial gray soils in the Sadarak plain, Nakhchivan AR. $<0.001 \mathrm{~mm}$ (section 1). (a) In totally arid stat; (b) while being saturated with glycerin; (v) while heating $550^{\circ} \mathrm{C}$ 
Aliyev: Impact of mineral formation on restoration of the soil structure

Table 2: Some physical-chemical characters of the inclined mountain alluvial gray soils in the Sadarak plain of Nakhchivan AR

\begin{tabular}{|c|c|c|c|c|c|c|c|c|c|}
\hline Line No. & $\begin{array}{l}\text { Name of } \\
\text { the section }\end{array}$ & Depth by/cm & $\begin{array}{c}\text { Field humid } \\
\text { capacity } \%\end{array}$ & $\begin{array}{c}\text { Hygroscopic } \\
\text { moisture \% }\end{array}$ & pH & $\begin{array}{c}\text { Bulky weight } \\
\mathrm{g} / \mathrm{cm}^{3}\end{array}$ & $\mathrm{CO}_{2} \%$ & $\begin{array}{c}\mathrm{CaCO}_{3} \text { according } \\
\text { to } \mathrm{CO}_{2}-\%\end{array}$ & $\begin{array}{c}\text { Humus } \\
\%\end{array}$ \\
\hline \multirow[t]{6}{*}{1} & \multirow{6}{*}{$\begin{array}{l}\text { 1. Sadarak } \\
\text { plain } \\
\text { mountain } \\
\text { illuvial gray } \\
\text { soils }\end{array}$} & A $0-20$ & 6.80 & 4.84 & 7.9 & 1.07 & 8.41 & 19.1 & 1.33 \\
\hline & & A/B 20-38 & 18.22 & 4.54 & 8.1 & 1.15 & 8.58 & 19.5 & 1.20 \\
\hline & & $\mathrm{B}_{1} 38-59$ & 20.67 & 4.41 & 7.8 & 1.25 & 7.39 & 16.7 & 0.81 \\
\hline & & $\mathrm{B}_{2} 59-88$ & 19.82 & 4.95 & 7.9 & 1.27 & 6.48 & 14.7 & 0.72 \\
\hline & & $\mathrm{B} / \mathrm{C} 88-26$ & 17.91 & 4.79 & 8.0 & t.e & 6.48 & 14.7 & 0.47 \\
\hline & & C $126-160$ & 18.54 & 2.62 & 7.9 & t.e & 6.48 & 14.7 & 0.30 \\
\hline
\end{tabular}

Table 3: Some physical-chemical characters of the soddy mountain meadow soils in the Shahbuz region of Nakhchivan AR

\begin{tabular}{|c|c|c|c|c|c|c|c|c|}
\hline Line No. & $\begin{array}{l}\text { Name of } \\
\text { the section }\end{array}$ & Depth by/cm & $\begin{array}{c}\text { Field humid } \\
\text { capacity } \%\end{array}$ & $\begin{array}{c}\text { Hygroscopic } \\
\text { moisture \% }\end{array}$ & $\begin{array}{c}\text { Bulky } \\
\text { weight } \mathrm{g} / \mathrm{cm}^{3}\end{array}$ & $\mathrm{Co}_{2} \%$ & $\begin{array}{c}\mathrm{CaCO}_{3} \text { according } \\
\text { to } \mathrm{Co}_{2} \%\end{array}$ & $\begin{array}{c}\text { Humus } \\
\%\end{array}$ \\
\hline \multirow[t]{6}{*}{3} & \multirow{6}{*}{$\begin{array}{l}\text { 18. Shahbuz } \\
\text { region } \\
\text { Gejazur } \\
\text { zone soddy } \\
\text { mountain } \\
\text { meadow } \\
\text { soils }\end{array}$} & A $0-10$ A/B $10-26$ & 21.04 & 6.99 & t.e & 1.00 & 2.28 & 3.07 \\
\hline & & $\mathrm{B}_{1} 26-48$ & 24.08 & 8.66 & “_ $"$ & 1.00 & 2.28 & 3.31 \\
\hline & & $\mathrm{B}_{2} 48-65$ & 24.96 & 8.42 & $-"$ & 0.37 & 0.85 & 2.06 \\
\hline & & $\mathrm{B} / \mathrm{C} 65-78$ & 21.22 & 8.51 & $-"$ & 0.75 & 1.71 & 1.91 \\
\hline & & C 78-105 & 20.84 & 7.71 & " & 0.60 & 1.85 & 1.21 \\
\hline & & & 17.00 & 5.06 & _" & 0.45 & 0.85 & 1.02 \\
\hline
\end{tabular}

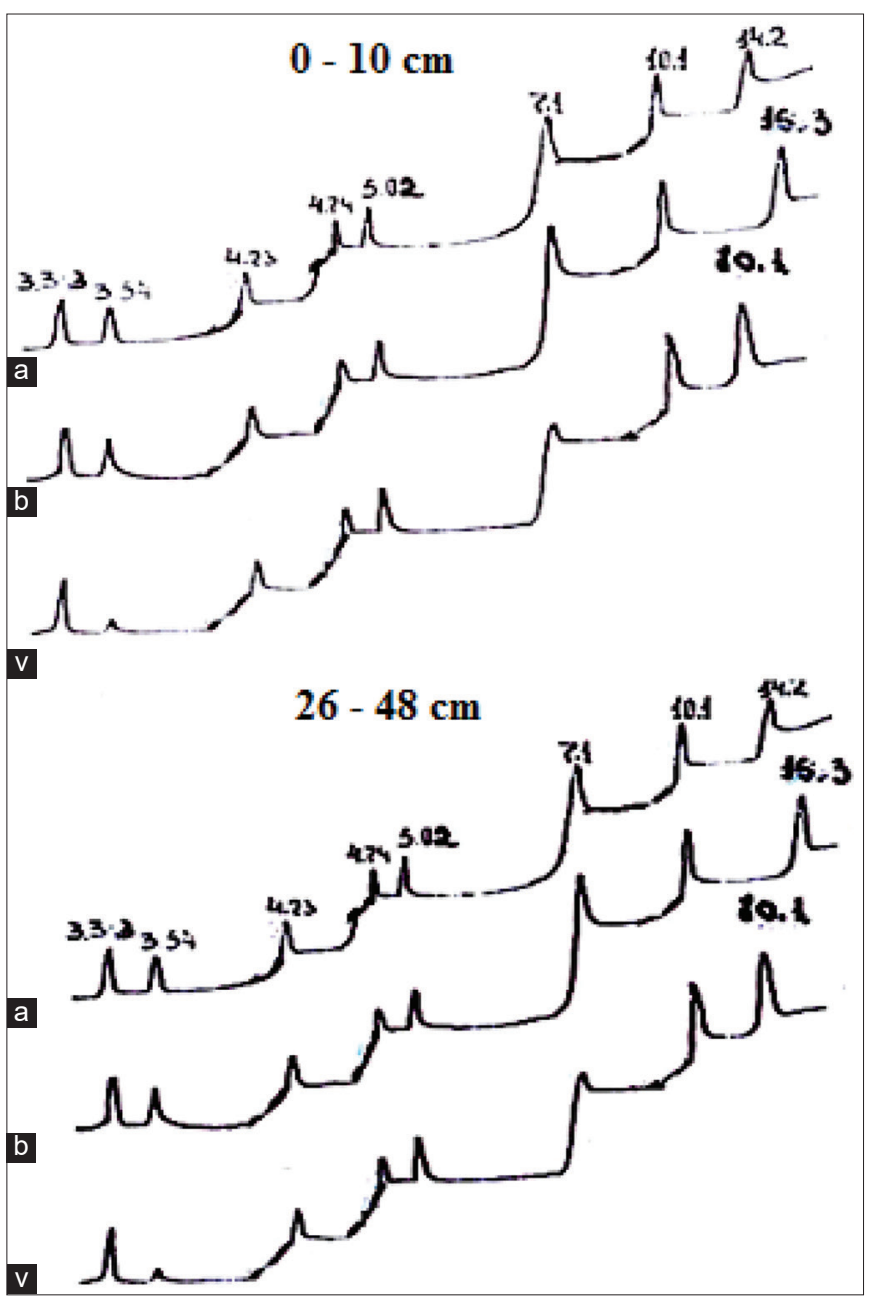

Figure 6: Definition of Roentgen diffractograms in silt fractions from soddy mountain meadow soils, Nakhchivan AR. (a) In totally arid situation; (b) while being saturated with glycerin; (v) while heating $550^{\circ} \mathrm{C}$

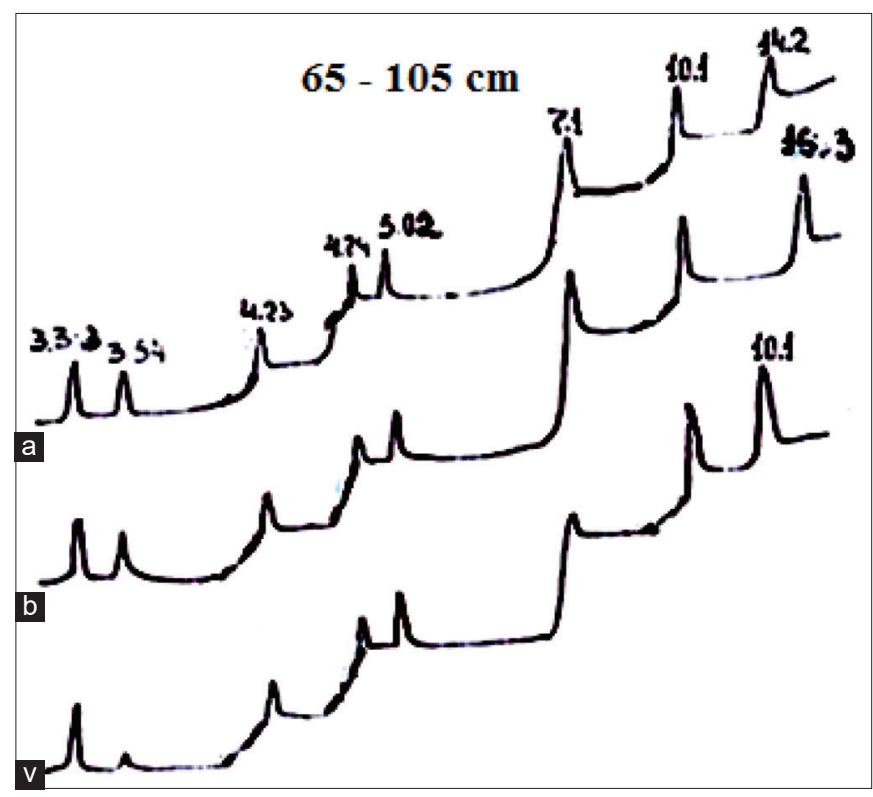

Figure 7: Definition of Roentgen diffractograms in silt fractions of the soddy mountain meadow soils, Nakhchivan AR. $<0.001 \mathrm{~mm}$ (Section 17). (a) In totally arid situation; (b) While being saturated; (v) While heating $550^{\circ} \mathrm{C}$

high dispersion minerals, superiority of the initial minerals.

Somewhat increase of the high dispersion minerals in silt fractions of the mean inclined plain zone soils is a reason for a gradual decrease of the initial minerals. This influences the formation of the soil minerals.

When the soil profile is wholly formed, then a process of high dispersion mineral formation 
quickens. However, the initial minerals formation weakens.

If the soddy mountain meadow, soddy-meadow soils in the both zones consist of the initial minerals majority, then they cause majority of the high dispersion minerals and decrease of the initial minerals in the mean plain inclined soils.

\section{CONCLUSIONS}

1. The soils selected for bioclimatic features, formed in Nakhchivan AR differ from one another. The soddy mountain meadow soils have high humus $-3.31 \%$, high hygroscopic humidity $5.06-8.51 \%$, and high field moisture capacity $17.00-24.96 \%$, but the mean inclined plain zone mountain alluvial gray soils possess weak humus $1.33 \%$, weak bulky weight $1.07-$ $1.27 \mathrm{~g} / \mathrm{cm}^{3}$, and weak field humid capacity $6.80-20.67 \%$.

2. They cause increase of the high dispersion minerals in mean inclined plain zone soils and diminish, the initial minerals possess superiority in soddy mountain meadow and soddy-meadow soils.

3. If the soil-forming process is ancient and morphogenetic layers wholly develop the silt fractions possess superiority in those soils.

\section{REFERENCES}

1. Avakulov VV. Initial Soils in the Natural and Anthropogenic Ecosystems. Toliati: Synopsis of Doctoral Thesis; 2012. p. 48.

2. Abasov MA. Geomorphology of Nakhchivan ASSR.
Baku: "Elm" (Science); 1970. p. 147.

3. Andronitskov VL, Lebedeva IN, Toikonochov VD, Papkova EI. Problems in anthropogenic evolution of soil cover USSR. In: Anthropogenic and Natural Evolution of Soils and Soil Cover. Pushchino: Mehwish; 1989.

4. Gerasimov MI, Gubi SV, Shoba SA. Soil Micromorphology in the Natural Zones of USSR. Pushino, Moscú: ONTI PNC RAS; 1992. p. 215.

5. Gorbunov NI. Mineralogy and Physical Chemistry of Soils. Moscow: Publishing House Nauka; 1978. p. 293.

6. Gradusov BP. Mixed-Stratified Minerals in Soils. Moscow: Publishing House Nauka; 1976. p. 126.

7. Dobrovolsky VV. Composition of fine earth in friable soil forming rocks from Eastern European plains and genesis. Soil Sci 2005;3:345-55.

8. Kurochkina GI, Pinsky DA, Fedotov GN, Khainos I, Sokolovsky Z, Tsesla I. Change of the structural organization of precipitation in gleyey minerals and soils under polyelectrolyte impact. Soil Sci 2013;8:993-1004.

9. Ivanov GI. Soil Formation in the South of Far East. Moscow: Publishing House Nauka; 1976. p.200.

10. Sokolova TA, Tolpeshta IL, Sizemskaya ML. Soil formation initial stage and bottom of the artificial decrease in thirty year growth under semi desert condition. Soil Sci 2013;8:899-910.

11. Sokolova TA. Fundamental leadership on soil mineralogy. Soil Sci 2003;8:12.

12. Skvortsova EE, Morozov DR. Micromorphometric classification and diagnostics of the first space structure of soils. Soil Sci 1993;6:49-56.

13. Chidzhikova NP, Verkhovets NA, Vladichensky AS. Conduct of the gleyey fraction components in the fashion ecosystems of lizimetres. Soil Sci 2006;9:1088-97.

14. Chidzhikova NP, Kharitonova GV, Matyushkina LA, Konovalova NS, Stenina AS. Differentation of the laminated silicates and biogenic silicon oxide in the meadow whitish Middle Amur Lowland. Soil Sci 2013;8:980-93.

15. Chidzhikova PN. Map of the Soil Forming Rocks European Part of USSR: Composed in the Museum of Agriculture. Moscow: Moscow State University; 1969. 